\title{
PENGARUH SISTEM PELAYANAN DAN OPERASIONAL PEGADAIAN SYARI'AH TERHADAP JUMLAH PINJAMAN NASABAH DI PEGADAIAN SYARI'AH KOTA PADANGSIDIMPUAN
}

\author{
Oleh: Rosnani Siregar \\ Email: rosnanisiregar26@gmail.com \\ Dosen Fakultas Ekonomi dan Bisnis Islam IAIN Padangsidimpuan
}

\begin{abstract}
Sharia Pawnshop stood in 2003. Sharia Pawnshop is standing along with the development of other sharia banks. During the period from its inception until now the final year of 2008 certainly has a pretty good development. Theoretically this development is possible because of their good service to customers. The definition of pawn business in general is the activity of guaranteeing valuables to certain parties (in this case Perum Pegadaian) in order to obtain some money, and the guaranteed goods can be redeemed in accordance with the agreement between the customer with the pawnshop institution. Method of research analysis used in determining the results of this first hypothesis are descriptive, the second hypothesis is descriptive, the third hypothesis is descriptive, the fourth hypothesis is descriptive, the fifth and sixth hypotheses are by weber cambboan based on statistical data through simple correlation. Descriptive means, the author seeks to describe data and facts in a comparative manner. There is a mutual influence between service system and operational system of Perum Pegadaian Syari'ah Alaman Bolak Kota Padangsidimpuan towards the amount of loan turnover loaned to the customer
\end{abstract}

Keywords : Operational and Services of Sharia Pawnshop

\section{PENDAHULUAN}

\section{A. Latar Belakang Masalah}

Sistem ekonomi dalam Islam tidak hanya didasarkan pada undang-undang saja tetapi juga dilandasi oleh ajaran-ajaran agama Islam yaitu al-Qur'an dan Sunnah Nabi saw. ${ }^{1}$ Asumsi Rasionalitas dalam ekonomi syari'ah menganut asas bahwa ekonomi itu tidak hanya untuk pemenuhan memperbanyak kekayaan secara moneter akan tetapi terdapat tujuan-tujuan lain yang berhubungan dengan prestise, persahabatan, cinta, kekuasaan, menolong sesama, menciptakan karya seni, dan menjadikan seseorang lebih baik serta orang-orang disekitarnya. ${ }^{2}$ 
Ketika seseorang berusaha untuk untuk mendapatkan tujuan-tujuan tersebut maka upaya yang harus dilakukan adalah membangun subuah unit usaha. Ada beberapa langkah yang harus dikerjakan seseorang ketika ia memulai usaha tersebut yaitu memilih peluang dan jenis usaha, mendidirkan dan membnetuk badan usaha, mempersiapkan kegiatan usaha, dan merancang kegiatan usaha $^{3}$ dan harus menganut sistem ekonomi syari'ah yaitu sistem perekonomian yang didasarkan pada al-Qur'an dan sunnah untuk mewujutkan kemaslahatan dan menolak kemudharatan umat manusia. ${ }^{4}$

Salah satu bentuk lembaga ekonomi syari' yang berkembang saat ini adalah Penggadaian Syari'ah. Lembaga ini memiliki visi pada tahun 2013 pegadaian menjadi "Champion" dalam pembiayaan mikro dan kecil berbasis gadai dan fiducia bagi masyarakat menengah kebawah. Sedangkan misinya adalah pertama; membangun program pemerintah meningkatkan kesejahteraan rakyat khususnya. Kedua; memberikan manfaat kepada pemangku kepentingan dan melaksanakan tata kelola perusahaan yang baik secara konsisten, dan ketiga; melaksanakan usaha lain dalam rangka optimalisasi sumber daya. ${ }^{5}$ Pegadaian syari'ah saat ini menjadi salah satu pilihan masyarakat. Dalam laporan Antara News diberitahukan bahwa di daerah Semarang Pegadaian syari'ah Cabang Majapahit Semarang sekitar tahun 2007 diserbu oleh nasabah. ${ }^{6}$

Kandisi yang sama juga dialami oleh Perusahaan Umum (Perum) Pegadaian Pusat, nasabah yang menggunakan gadai syari'ah meningkat sekitar 47,151 orang. Perbandingannya ialah pada bulan Nopember 2008 nasabah mencapai 518.665 orang, jumlah ini meningkat pada bulan Desember 2008 menjadi 565.816 nasabah. $^{7}$

Untuk daerah Padangsidimpuan Pegadaian Syari'ah berdiri pada tahun 2003. Pegadaian syari'ah ini berdiri seiring dengan berkembangnya bank-bank syari'ah lainnya. Selama kurun waktu dari awal berdirinya sampai saat sekarang ini tahun 2008 akhir tentunya memiliki perkembangan yang cukup baik. Secara teoritis perkembangan ini dimungkinkan karena pelayanan mereka yang cukup baik terhadap nasabah. Sedangkan faktor kedua adalah sistem operationalnya yang tidak mengandung unsur riba sehingga memberikan keuntungan bagi kedua belah pihak. Hal inilah yang membuat peneliti merasa tertarik untuk meneliti apakah perkembangan Pegadaian Syari'ah ini dipengaruhi oleh Sistem pelayanan dan operationalnya, dan seberapa besar pengaruh tersebut. Tulisan ini akan dituangkan dalam bentuk peneltian yang berjudul: "Pengaruh Sistem Pelayanan dan Operasional Pegadaian Syari'ah terhadap Jumlah Pinjaman Nasbah di Pegadaian Syari'ah Kota Padangsidimpuan” 


\section{B. Perumusan Masalah}

Adapun yang menjadi rumusan masalah dalam penelitian ini adalah :

1. Bagaiaman sistem pelayanan yang diterapkan di pegadaian syari'ah?

2. Bagaiaman sistem operasional pegadaian syari'ah?

3. Bagaiaman pengaruh sistem pelayanan dan operasinolnya terhadap jumlah pinjaman nasabah?

\section{Kajian Teoritis}

\section{Pengertian Usaha Gadai}

Pengertian usaha gadai secara umum adalah kegiatan menjaminkan barangbarang berharga kepada pihak tertentu (dalam hal ini Perum Pegadaian) guna memperoleh sejumlah uang, dan barang yang dijaminkan dapat ditebus kembali sesuai dengan perjanjian antara nasabah dengan lembaga pegadaian. ${ }^{8}$

Dari pengertian tersebut dapat diuraikan beberapa ciri-ciri yang dimiliki usaha pegadaian yaitu:

1. Terdapat barang-barang berharga yang digadaikan

2. Nilai Jumlah pinjaman tergantung pada nilai barang yang digadaikan.

3. Barang yang digadaikan dapat ditembus kembali.

Dalam perspektif syara' gadai diistilahkan dengan rahn yaitu menjadikan suatu barang yang mempunyai nilai harta dalam pandangan syara' sebagai jaminan hutang, yang memungkinkan untuk mengambil hutang dari seluruh atau sebagian dari barang tersebut. ${ }^{9}$ Dimana para ulama saling berbeda pendapat dalam mendepenisikannya diantaranya Ulama Syafi' Iyah. ${ }^{10}$ Ulama Hambliyah, ${ }^{11}$ dan Ulama Malikiyah. ${ }^{12}$ Ahmad Azhar mengatakan rahn adalah perjanjian menahan sesuatu barang sebagai tanggungan utang, atau menjadikan sesuatu benda bernilai menurut pandangan syara' sebagai tanggungan marhum bih sehingga dengan adanya tanggungan hutang tersebut seluruh atau sebagian hutang dapat diterima. ${ }^{13}$ Muhammad Syafi'I Antonio mengatakan bahwa gadai syari'ah atau rahn adalah menahan salah satu harta milik nasabah (rahin) sebagai barang jaminan (marhun) atas hutang pinjaman (marhun bih) yang diterimanya. Dengan demikian, pihak yang menahan atau penerima gadai (murtahin) memperoleh jaminan untuk dapat mengambil kembali seluruh atau sebagian piutangnya. ${ }^{14}$ 


\section{Latar Belakang Berdirinya Pegadaian Syari'ah di Indonesia}

Pegadaian Syari'ah lembaga ini muncul karena desakan masyarakat muslim untuk melaksanakan transaksi gadai sesuai dengan ketentuan syara'. Usaha ini pertama kali dilakukan oleh Bank Muamalat Indonesia (BMI) yang beraliansi dengan Perum Pegadaian. Selain aliansi kedua lembaga ini gadai syari'ah juga dilakukan oleh Bnakbank umum Syari'ah seperti Bank Syari'ah Mandiri (BSM), dan bank-bank umum lainnya yang membuka unit usaha syari'ah.

Melihat adanya peluang dalam mengimplementasikan praktek gadai berdasarkan prinsip syari'ah, Perum Pegadaian yang telah bergelut dengan bisnis pegadaian konvensional selama beratus-ratus tahun lebih berinisiatif untuk mengadakan kerja sama dengan PT Bank Muamalat Indonesia dalam mengusahakan peraktek gadai syari'ah sebagai diversifikasi usaha gadai yang sudah dilakukan sehingga pada bulan Mei 2002 ditanda tangani sebuah kerja sama antara kedua belah pihak untuk menyalirkan gadai syari'ah yaitu BMI sebagai penyandang dana).

Untuk menglola kegiatan dimaksud, dibentuk Unit Layanan Gadai Syari'ah sebagai gerai layanan tersendiri namun masih satu atap pada cabang-cabang Perum Pegadaian. Cabang pertama yang terpilih ketika itu adalah Perum Pegadaian Cabang Dewi Sartika yang menerima pembiayaan modal dari BMI sebesar Rp.1.550.000.000,00 dan sejumlah uang sebesar Rp. 24.435.000.000.00 yang diperuntukkan bagi perluasan jaringan Unit Layanan Gadai Syari'ah (sekaran, Cabang Pegadaian Syari'ah). ${ }^{15}$

Berdasarkan perubahan status pegadaian maka lembaga syari'ah mulai melirik lembaga pegadaian. Bank Muamalat dalam salah satu langkah aliasinya telah menggandeng Perum Pegadaian. Bentuk kerjasama Bank Muamalat dengan Perum Pegadaian yaitu memberikan konstribusi dalam sistem gadainya sedang Bank Muamalat memberikan muatan sistem syari'ah. ${ }^{16}$

Terbitnya PP. No.10 tanggal 1 April 1990 dapat dikatakan menjadi tonggak awal kebangkitan Pegadaian Syari'ah. Satu hal yang perlu dicermati bahwa PP. tersebut menegaskan misi yang harus diemban oleh pegadaian untuk mencegarh praktek riba. Misi ini tidak berubah hingga terbitnya PP. 103/2000 yang dijadikan sebagai landasan kegiatan usaha perum pegadaian Syari'ah sampai sekarang.

\section{Pelaksanaan Produk dan Layanan serta Mekanismenya}

a. Produk dan Layanan 
Pegadaian Syari'ah melayani fasilitas kredir gadai berdasarkan prosedur yang praktis, cepat dan menenteramkan. Dalam Pedoman Operasional Gadai Syari'ah (GOPS) Perum Pegadaian pada dasarnya dapat melayani produk dan jasa sebagai berikut:

i. Pemberian pinjaman atau pembiayaan atas dasar hukum gadai syari'ah ( $r a h n)$.

ii. Penaksiran nilai barang, yaitu Pegadaian Syari'ah memberikan jasa penaksiran atas nilai suatu barang yang dilakukan oleh calon nasabah..

iii. Penitipan barang (ijarah), yaitu penyelenggaraan penitipan barang orang-orang yang menitipkan barang ke kantor Pegadaian Syari'ah berdasarkan alasan faktor keamanan dan alasan lainnya..

iv. Gold Counter (gerai emas) yaitu temat penjualan emas yang menawarkan keunggulan dan keasliannya.

b. Mekanisme akad

Transaksi yang digunakan oleh Pegadaian Syari'ah adalah teransaksi yang menggunakan dua akad yaitu akad rahn dan akad ijarah penjelasan rinci kedua akad tersebut tertera pada lembaran SBR (Surat Bukti Rahn) sehingga setiap nasabah memahami apa yang hendak dilakukan. Meskipun secara konsep akad dimaksud mempunyai perbedaan, namun dalam teknis pelaksanaannya nasabah tidak perlu mengadakan akad dua kali. Sebab satu lembar SBR yang ditanda tangani nasabah sudah mencakup kedua akad dimaksud.

c. Mekanisme Penetapan Biaya mencakup:

i. Penggolongan Pinjaman (marhun bih) dan biaya administrasi

ii. Tarif Jasa Simpanan (Ijarah)

iii. Harga Minimum Penjualan/pelelangan

d. Tata Cara Pelaksanaan antara lain:

i. Prosedur memperoleh pinjaman (marhun bih)

ii. Tata cara pelaksanaan pencairan pinjaman (marhun bih)

iii. Prosedur Pelunasan Kredit Gadai Syari'ah

\section{Hasil Penelitian}

\section{Perkembangan Jumlah Nasabah}

Perkembagngan jumlah nasabah Perum Pegadaian Syari'ah Alam Bolak Kota Padangsidimpuan daritahun 2006 sampai tahun 2009 cukup menggembirakan pada tahun 2006 jumlah nasabhnyanya sebanyak 7818 orang kemudian meningkat hingga pada tahun 2009 mencapai 14181 nasabah. Pencapaian ini melebihi target yang 
direncanakan oleh Perum Pegadaian ini. Untuk lebih jelasnya dapat dilihat pada tabel di bawah ini:

Tabel:

Perkembangan Jumlah Nasabah Pegadaian Syari'ah Kota Padangsidimpuan

\begin{tabular}{|c|c|c|c|c|}
\hline No & Tahun & $\begin{array}{c}\text { Target Jumlah } \\
\text { Nasabah/Potongan } \\
\text { Barang Jaminan }\end{array}$ & $\begin{array}{c}\text { Realisasi } \\
\text { Pencapaian }\end{array}$ & Keterangan \\
\hline 1 & 2006 & 5985 & 7818 & \\
\hline 2 & 2007 & 8209 & 11304 & \\
\hline 3 & 2008 & 17456 & 13917 & \\
\hline 4 & $\begin{array}{c}\text { s.d Nop } \\
2009\end{array}$ & 16429 & 14181 & \\
\hline
\end{tabular}

\section{Perkembangan Jumlah Uang Pinjaman}

Perkembangan jumlah uang pinjaman yang disalurkan oleh Perum Pegadaian Syari'ah Alam Bolak Kota Padangsidimpuan mengalami perkembangan dari tahun ketahun, dari tahun 2006 sampai dengan tahun 2009 terlihat perkembangan jumlah uang pinjaman yang signifikan. Untuk lenih jelasnya dapat kita lihat pada tabel di bawah ini:

Tabel:

Perkembangan Jumlah Uang Pinjaman

\begin{tabular}{|c|c|c|c|c|}
\hline No & Tahun & $\begin{array}{c}\text { Target Uang Pinjaman yang } \\
\text { Disalurkan }\end{array}$ & $\begin{array}{c}\text { Realisasi } \\
\text { Pencapaian }\end{array}$ & Keterangan \\
\hline 1 & 2006 & $8.400 .000 .000 .-$ & $14.508 .528 .000 .-$ & \\
\hline 2 & 2007 & $15.000 .000 .000 .-$ & $31.285 .581 .000 .-$ & \\
\hline 3 & 2008 & $42.232 .500 .000 .-$ & $42.420 .915 .000 .-$ & \\
\hline 4 & $\begin{array}{c}\text { s.d Nop } \\
2009\end{array}$ & $63.252 .319 .000 .-$ & $51.961 .431 .000 .-$ & \\
\hline
\end{tabular}


3. Struktur Organisasi Perum Pegadaian Syari'ah ${ }^{17}$

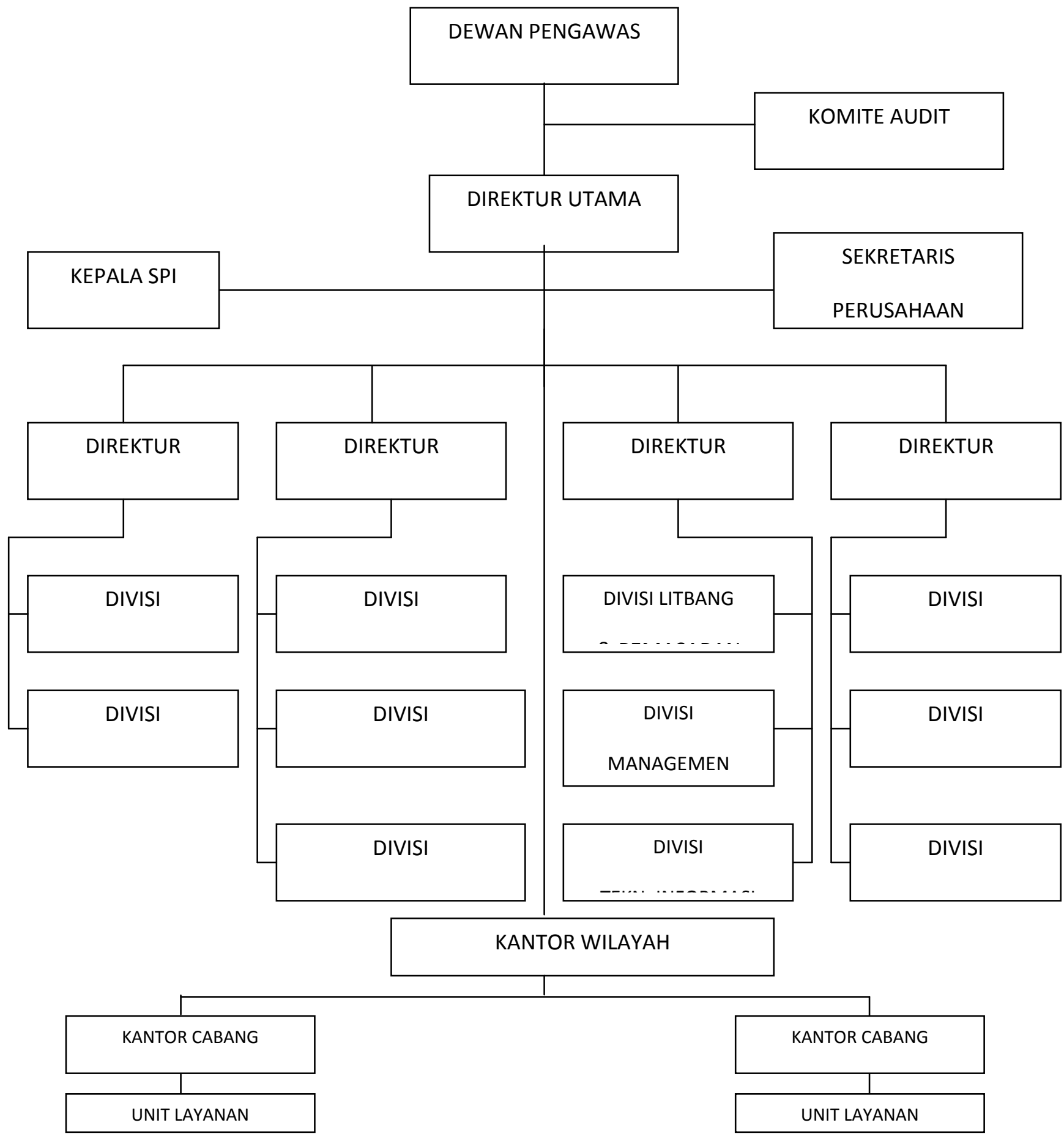




\section{Metode Penelitian}

\section{Objek penelitian}

Adapun objek penelitian dalam penelitian ini adalah:

a. Sistem pelayanan yang diterapkan oleh Pegadaian Syari'ah dan tanggapan nasabah terhadap sistem pelayanan mereka.

b. Sistem Operasional yang diterapkan dalam Pegadaian Syari'ah dan tanggapan nasabah terhadap sistem operasional tersebut.

c. Pengaruh sistem pelayanan dan operational Pegadaian Syari'ah terhadap jumlah pinjaman nasabah.

\section{Unit Penelitian}

Pegadaian Syari'ah Kota Padangsidimpuan diambil menjadi objek penelitian secara purposive, karena lembaga ini merupakan lembaga ekonomi syari'ah yang beroperasi di Kota Padangsidimpuan.

\section{E. Populasi Dan Sampel Nasabah Pegadaian Syari'ah Kota Padangsidimpuan}

Populasi adalah nasabah yang meminjam di Perum Pegadaian Syari'ah Alaman Bolak Kota Padangsidimpuan tahun 2006-2009. Dari keseluruhan nasabah tersebut, yang masih punya keterkaitan hutang dengan Pegadaian Syari'ah hanya tinggal sekitar 153 nasabah. Brdasarkan tabel di atas, maka sampel penelitian ini adalah 60 orang yang dapat diambil datanya. Artinya penelitian ini mengambil sampel $30 \%$ dari populasinya. ${ }^{18}$

\section{F. Instrumen Teknik Pengumpulan Data}

Jenis data pada penelitian ini sifatnya gabungan antara kualitatif dan kuantitatif, dan Instrumen yang digunakan untuk variabel sistem pelayanan diperoleh melalui pendapat para nasabah sedangkan untuk pariabel sistem operationalnya bagaiman pendapat nasabah tentang hal tersebut diambil juga dari nasabah ditambah dengan pihak Pegadaian Syari'ah untuk menguji kebenaran data yang diberikan nasabah.

Data mengenai pendapat nasabah tentang sistem pelayanan dan operasional Pegadaian Syari'ah terhadap Pegadaian Syari'ah didapatkan dengan menggunakan angket dan wawancara dalam bentuk skala interval dengan mengacu pada Skala Interval Likert. Setiap item pertanyaan yang diajukan sesuai 
dengan indikator variabel. Masing-masing pernyataan terdiri dari lima option pilihan jawaban. Penentuan bobot nilai setiap option jawaban ditentukan adalah 5,4,3,2,1 untuk item positif, dan 1,2,3,4,5 untuk jawaban yang negatif.

Tabel 3. Inti Pertanyaan Sistem Opersional Pegadaian Syari'ah

\section{Sistem Operational Pegadaian Syari’ah di Kota Padangsidimpuan}

\begin{tabular}{|c|l|l|}
\hline No & \multicolumn{1}{|c|}{ Indikator } & \multicolumn{1}{|c|}{$\begin{array}{c}\text { Nomor } \\
\text { Butir Item }\end{array}$} \\
\hline 1. & Perkembangan Pegadaian Syari'ah di Kota Padangsidimpuan & $\begin{array}{l}2.4 .8 .9 .10 .11 .13 .15 .1 \\
7.20\end{array}$ \\
\hline 2. & $\begin{array}{l}\text { Tanggapan nasabah terhadap sistem al-qard al-hasan dan } \\
\text { mudharabah dalam Pegadaian Syari'ah. }\end{array}$ & $\begin{array}{l}1.3 .5 .6 .7 .12 .14 .16 .18 . \\
19\end{array}$ \\
\hline & Jumlah & 20 item \\
\hline
\end{tabular}

\section{Pendapat responden terhadap sistem pelayanan Pegadaian Syari'ah}

\begin{tabular}{|c|l|c|}
\hline No & \multicolumn{1}{|c|}{ Indikator } & \multicolumn{1}{c|}{$\begin{array}{c}\text { Nomor } \\
\text { Butir Item }\end{array}$} \\
\hline 1. & $\begin{array}{l}\text { Metode pelayanan yang dilakukan oleh pegawai } \\
\text { Pegadaian Syari'ah } \\
2.4 .6 .7 .8 .9 .11 .13 .16 .1 \\
9\end{array}$ \\
\hline 2. & $\begin{array}{l}\text { Tanggapan nasabah terhadap sistem sistem } \\
\text { pelayanan tersebut. }\end{array}$ & $\begin{array}{l}1.3 .5 .10 .12 . .14 .15 .17 . \\
18.20\end{array}$ \\
\hline & \multicolumn{1}{|c|}{ Jumlah } & 20 \\
\hline
\end{tabular}

1. Pengujian Persyaratan Analisis

Sebelum pengujian hipotesis penelitian dilakukan dalam analisis statistik, maka perlu dilakukan uji prasyarat analisis yaitu uji normalitas dan uji linieritas. Pengeujian tersebut akan dijabarkan berikut ini

a. Uji Normalitas

Uji normalitas dapat dihitung dengan rumus Chi-Kuadrat. Data dari setiap variabel dikatakan normal bila nilai chi-kuadrat hitung lebih kecil dari nilai chikuadrat tabel pada taraf signifikan 5\%. Berikut ini dapat disajikan ringkasan analisis uji normalitas dari setiap variabel penelitian. Perhitungan dilakukan dengan komputer program statistika (SPSS versi 12) selanjutnya hasil perhitungan dapat dilihat pada lampiran. 
Tabel

Rangkiman Hasil Analisis Uji Kenormalan Data

\begin{tabular}{|c|c|c|c|}
\hline Variabel Penelitian & Df & $\begin{array}{c}\text { Chi-Kuadrat } \\
\text { Hitung }\end{array}$ & $\begin{array}{c}\text { Chi-Kuadrad } \\
\text { Tabel }\end{array}$ \\
\hline $\begin{array}{c}\text { Sistem Pelayanan Pegadaian } \\
\text { Syari'ah }\end{array}$ & 22 & 26.633 & 33.924 \\
\hline $\begin{array}{c}\text { Sistem Operasional Pegadaian } \\
\text { Syari'ah }\end{array}$ & 22 & 24.333 & 33.924 \\
\hline Jumlah Omset & 7 & 9.067 & 14.067 \\
\hline
\end{tabular}

Uji kenormalan data variabel Sistem Pelayanan Perum Pegadaian Syari'ah Alaman Bolak Kota Padangsidimpuan diperoleh nilai chi-kuadrat hitung sebesar 26.633 dan nilai chi kuadrat tabel dengan Df $=22$ sebesar pada taraf signifikan 33.924. Jadi dari hasil tersebut di dapat nilai chi-kuadrat hitung lebih kecil dari chi-kuadrat tabel yaitu $26.633<33.924$ pada taraf signifikan 5\%. Dengan demikian dapat disimpulkan bahwa data variabel Sistem Pelayanan Perum Pegadaian Syari'ah Alaman Bolak Kota Padangsidimpuan berdistribusi secara normal pada taraf signifikan 5\%.

Kemudian data sistem operasional Perum Pegadaian Syari'ah Alaman Bolak Kota Padangsidimpuan diperoleh nilai chi-kuadrat hitung sebesar 24.333 dan nilai chi kuadrat tabel dengan $\mathrm{Df}=22$ sebesar 33.924 pada taraf signifikan 5\%. Jadi dari hasil tersebut di dapat nilai chi-kuadrat hitung lebih kecil dari chikuardat tabel yaitu $24.333<33.924$ pada taraf signifikan 5\%. Dengan demikian dapat disimpulkan bahwa data variabel Sistem Pelayanan Perum Pegadaian Syari'ah Alaman Bolak Kota Padangsidimpuan berdistribusi secara normal pada taraf signifikan $5 \%$.

Kemudian untuk melihat normal tidaknya data melalui grafik yaitu memperhatikan sebaran data (titik-titik) pada sumbu diagonal grafik tersebut dan pengambilan keputusan sesuai dengan batasan berikut:

1. Jika data (titik) menyebar disekitar garis diagonal dan mengikuti arah garis diagonal, maka model regresi memenuhi asumsi normalitas.

2. Jika data (titik) menyebar jauh dari garis diagonal dan atau tidak mengikuti arah garis diagonal, maka model regresi tidak memenuhi asumsi normalitas.

b. Uji Linieritas

Dalam menguji linieritas dilakukan antara variabel bebas dengan variabel terikat dalam persamaan regresi. Dalam penelitian ini variabel yang dimaksudkan adalah variabel sistem pelayanan Perum Pegadaian Syari'ah Alaman Bolak Kota 
Padangsidimpuan dengan jumlah omset pinjaman nasabah, dan variabel sistem operasional Perum Pegadaian Syari'ah Alaman Bolak dengan omset pinjaman nasabah. Analisis tersebut menggunakan Anova dan uji signifikansi garis regresi dengan melihat - p. Adapun hasil analisis sebagai berikut:

1) Hasil perhitungan untuk variabel sistem pelayanan Perum Pegadaian Syari'ah Alaman Bolak (X1) dengan jumlah omset pinjaman nasabah (Y) diperoleh $\mathrm{F}$ hitung $=209.332$ Dan nilai $\mathrm{P}=0.000$ Sebagai Kriteria linieritas, pada $\mathrm{P}<0.05$ maka korelasi antara variabel bebas dengan variabel terikat adalah linier. Berdasarkan kriteria tersebut maka dapat disimpulkan bahwa variabel sistem pelayanan Perum Pegadaian Syari'ah Alaman Bolak dengan variabel jumlah omset pinjaman nasabah adalah linier.

2) Hasil perhitungan untuk variabel sistem Operasional Perum Pegadaian Syari'ah Alaman Bolak (X2) dengan jumlah omset pinjaman nasabah (Y) diperoleh $\mathrm{F}$ hitung $=214.995$ dan nilai $\mathrm{P}=0.000$ Sebagai Kriteria linieritas, pada $\mathrm{P}<0.05$ maka korelasi antara variabel bebas dengan variabel terikat adalah linier. Berdasarkan kriteria tersebut maka dapat disimpulkan bahwa variabel sistem operasional Perum Pegadaian Syari'ah Alaman Bolak dengan variabel jumlah omset pinjaman nasabah adalah linier.

Hasil ringkisan uji linieritas antara variabel bebas dengan variabel terikat pada penelitian ini seperti terlihat pada tabel berikut:

Tabel:

Hasil Analisis Linieritas Garis Regresi

\begin{tabular}{|c|c|c|c|c|}
\hline NO & Korelasi & F Hitung & P Beda & Garis Linier \\
\hline 1 & X1 dengan Y & 209.332 & 0.000 & Linier \\
\hline 2 & X2 dengan Y & 214.995 & 0.000 & Linier \\
\hline
\end{tabular}

2. Pengujian Hipotesis

Pengujian persyaratan analisis menunjukkan bahwa skor setiap variabel penelitian telah memenuhi persyaratan untuk dilakukan pengujian statistik lebih lanjut. Sebelum pengujian hipotesisi, terlebih dahulu dilakukan analisis korelasi sederhana antara variabel bebas dengan variabel terikat. Analisis korelasi dihitung berdasarkan Product Moment, kemudian dilanjutkan dengan uji "t" untuk membuktikan keberartian hubungan antara variabel bebas dengan variabel terikat 
pada penelitian ini. Penelitian ini mempunyai 3 (tiga) buah hipotesis yang akan diuji. Lebih lengkapnya seperti pembahasan berikut:

a. hubungan antara variabel sistem pelayanan Perum pegadaian Syari'ah Alaman Bolak Kota Padangsidimpuan dengan jumlah omset pinjamannya.

Berdasarkan perhitungan korelasi antara variabel sistem pelayanan Perum pegadaian Syari'ah Alaman Bolak Kota Padangsidimpuan dengan jumlah omset pinjamannya diperoleh koefisiensi korelasi sebesar $r=0.885$ Lebih lanjut uji $t$ diperoleh nilai $\mathrm{t}$ hitung $=14.468$ Kemudian dengan melihat tabel berdasarkan $\mathrm{df}=59$ diperoleh $\mathrm{t}$ tabel $=2.000$ pada taraf signifikan 5\%. Disebut nilai t hitung $>\mathrm{t}$ tabel yaitu 14.468 $>2.000$, maka dapat disimpulkan bahwa hipotesis nol $($ Ho $\quad: \rho y \cdot x 1=0)$ ditolak atau hipotesis alternatif diterima.

Koefisien determinasi adalah kuadrat dari koefisien korelasi antara variabel bebas dengan variabel terikat. Dalam hal ini koefisien determinasi antara sistem pelayanan Perum Pegadaian Syari'ah Alaman Bolak Kota Padangsidimpuan dengan jumlah omset pinjamannya didapat sebesar $\mathrm{R}^{2}=78.32$ Ini berarti bahwa sebesar $78.32 \%$ variabel terikat jumlah omset pinjaman dengan sistem pelayanan Perum Pegadaian Syari'ah Alaman Bolak Kota Padangsidimpuan didapat $\mathrm{y}=-15.461+0.123 \mathrm{X} 1$

b. Hubungan antara sistem operasional Perum Pegadaian Syari'ah Alaman Bolak Kota Padangsidimpuan dengan omset pinjamannya Rumus hipotesisnya :

Ho: $\rho$ y . x $1=0$

Нa: $\rho$ y . x $1>0$

Berdasarkan perhitungan korelasi antara variabel sistem operasional Perum pegadaian Syari'ah Alaman Bolak Kota Padangsidimpuan dengan jumlah omset pinjamannya diperoleh koefisiensi korelasi sebesar $r=887$ Lebih lanjut uji t diperoleh nilai $\mathrm{t}$ hitung $=14.663$ Kemudian dengan melihat tabel berdasarkan $\mathrm{df}=59$ diperoleh $\mathrm{t}$ tabel $=2.000$ pada taraf signifikan 5\%. Disebut nilai $\mathrm{t}$ hitung $>\mathrm{t}$ tabel yaitu $14.663>$ 2.000, maka dapat disimpulkan bahwa hipotesis nol $($ Ho: $\rho$ y . x1 = 0$)$ ditolak atau hipotesis alternatif diterima. Hal ini berarti bahwa hipotesis penelitian yang berbunyi terdapat hubungan yang positif dan berarti antara sistem operasional Perum Pegadaian 
Syari’ah Alaman Bolak Kota Padangsidimpuan dengan omset pinjamannya diterima pada taraf signifikansi $5 \%$.

Koefisien determinasi adalah kuadrat dari koefisien korelasi antara variabel bebas dengan variabel terikat. Dalam hal ini koefisien determinasi antara sistem operasional Perum Pegadaian Syari'ah Alaman Bolak Kota Padangsidimpuan dengan jumlah omset pinjamannya didapat sebesar $\mathrm{R}^{2}=78.67$ Ini berarti bahwa sebesar $78.67 \%$ variabel terikat jumlah omset pinjaman dengan sistem operasional Perum Pegadaian Syari'ah Alaman Bolak Kota Padangsidimpuan didapat $\mathrm{y}=-15.531+0.267 \mathrm{X} 2$

Berdasarkan perhitungan korelasi antara sistem pelayanan (X1) dan sistem operasional (X2) Perum Pegadaian Syari'ah Alaman Bolak Kota Padangsidimpuan dengan jumlah omset pinjaman yang diberikan kepada nasabah, diperoleh koefisien korelasi sebesar $\quad r=0.901$. Lebih lanjut dilakukan uji t fiperoleh nilai $\mathrm{t}$ hitung $=$ 5.678 Kemudian dengan melihat tabel berdasarkan $\mathrm{df}=59$ diperoleh $\mathrm{t}$ tabel $=2.000$ pada taraf signifikan 5\%. Disebabkan nilai $\mathrm{t}$ hitung $>\mathrm{t}$ tabel yaitu $5.678>2.000$ maka dapat disimpulkan bahwa bahwa hipotesis nol (Ho $: \rho \mathrm{y} . \mathrm{x} 1=0)$ ditolak atau hipotesis alternatif diterima. Hal ini berarti bahwa hipotesis penelitian yang berbunyi terdapat hubungan yang positif dan berarti antara sistem pelayanan dan sistem operasional Perum Pegadaian Syari'ah Alaman Bolak Kota Padangsidimpuan secara bersama-sama dengan jumlah omset peminjamannya kepada nasabah diterima pada taraf signifikansi $5 \%$.

Koefisien determinasi adalah kuadrat dari koefisien korelasi antara variabel bebas dengan variabel terikat. Dalam hal ini koefisien determinasi antara variabel sistem pelayanan dengan variabel sistem operasional dengan jumlah omset pinjaman kepada nasabah didapat sebesar $\mathrm{r}^{2}=81.18$ Ini bearti bahwa $81.18 \%$ variabel jumlah omset pinjaman dapat dijelaskan secara bersama-sama oleh variabel sistem pelayanan dan sistem operasional. Persamaan garis regresi antara variabel jumlah omset pinjaman dengan variabel sistem pelayanan dan sistem operasional Perum pegadaian Syari'ah Alamam Bolak Kota Padangsidimpuan di dapat $Y=-15.461+0.123$ X1 + 0.144X2

\section{Penutup}

\section{A. Kesimpulan}

Berdasarkan penelitian tersebut dapat diambil beberapa kesimpulan, yaitu: 
1. Terdapat pengaruh yang signifikan sistem pelayanan Perum Pegadaian Syari'ah Alaman Bolak Kota Padangsidimpuan terhadap jumlah omset pinjaman yang dipinjamkan kepada nasabah.

2. Terdapat pengaruh yang signifikan antara sistem operasional Perum Pegadaian Syari'ah Alaman Bolak Kota Padangsidimpuan terhadap jumlah omset pinjaman yang dipinjamkan kepada nasabah.

3. Terdapat pengaruh secara bersama-sama antara sistem pelayanan dan sistem operasional Perum Pegadaian Syari'ah Alaman Bolak Kota Padangsidimpuan terhadap jumlah omset pinjaman yang dipinjamkan kepada nasabah

\section{Catatan:}

${ }^{1}$ Muhammad Saddam, Ekonomi Islam (Sistem Ekonomi Menurut Islam), (Jakarta:Taramedia, 2002) Hlm., 15

${ }^{2}$ Adiwarman Karim, Ekonomi Mikro Islam, (Jakarta: IIIT Indonesia, 2002), Hlm.,29

${ }^{3}$ Muhammad Ismail Yusanto dan Muhammad Karebet Widjajakusuma, Menggagas Bisnis Islam, (Jakarta: Gema Isnsani, 2002) Hlm., 73

${ }^{4}$ Muhammad Saddam, op.cit, hln 34

${ }^{5}$ Kasmir, Bank dan Lembaga Keuangan Lainnya, (Jakarta: Raja Grapindo Persada, 2001), hlm 229

${ }^{6}$ Internet, Selasa, 6 Januari 2009, pukul 15.06 WIB

${ }^{7}$ Ibid.

${ }^{8}$ Kasmir, Bank dan Lembaga Keuangan Lainnya (Edisi Revisi 2001), (Jakarta: Rajawali Pers, 2001), hlm., 230

${ }^{9}$ Sayyid Sabiq, al-Fiqh al-Sunnah, (Beirut: Dar al-Fikr, 1995), jilid 3, hlm., 187

${ }^{10}$ Ibid, hlm., 188

${ }^{11}$ Abi Muhammad Abdullah bin Muhammad bin Ibn Qudamah, al-Mughny 'ala Mukhtashar alHarqiy, (Beirut: al-Dar al-Kutub al-Ilmiyah, 1994), jilid 4, hlm., 234

${ }^{12}$ Wahbah Zuhaily, al-Fiqh al-Islam wa Adillatuh, (Beirut: Dar al-fikr, 2002), jilid 4, hlm., 4208

${ }^{13}$ Ahmad Basyir, Hukum Islam tentang Riba, Utang Piutang Gadai, (Bandung: al-Ma'arif, 1983), hlm., 50

${ }^{14}$ Muhammad Syafi'I Antonio, Bank Syari'ah dari Teori ke Praktek, (Jakarta: Gema Insani Press, 2001), hlm., 128

${ }^{15}$ http:pp members.bumn-ri com/pegdaian/news.html, dikutip pada tanggal 13 april 2009

${ }^{16}$ Zainuddin Ali, Hukum Gadai Syari'ah, (Jakarta: Sinar Grapika, 2008), hlm. 17

${ }^{17}$ Sumber data: Customer Service Perum Pegadaian Syari'ah Alaman Bolak Kota Padangsidimpuan.

${ }^{18}$ Saifuddin Azwar, Metode penelitian, (Yogyakarta: Pustaka Pelajar, 1998), hlm., 84

\section{Daftar Pustaka}

Ali, Zainuddin. Hukum Gadai Syari'ah, Jakarta, Sinar Grapika, 2008

Azwar, Saifuddin. Metode penelitian, Yogyakarta, Pustaka Pelajat, 1998

Brosur Pegadaian Syari'ah Kota Padangsidimpuan. 
Basyir, Ahmad. Hukum Islam tentang Riba, Utang Piutang Gadai, Bandung, alMa'arif, 1983

Dumairy, Perekonomian Indonesia, Jakarta, Erlangga, 1996

Faisal, Sanafiyah. Format-format Penelitian Sosial,Jakarta, Rajawali Press, 1995

http:pp members.bumn-ri com/pegdaian/news.html, dikutip pada tanggal 13 april 2009

Internet, Selasa, 6 Januari 2009, pukul 15.06 WIB

Ibn Qudamah, Abi Muhammad Abdullah bin Muhammad bin. al-Mughny 'ala Mukhtashar al-Harqiy, Beirut, al-Dar al-Kutub al-Ilmiyah, 1994

Kasmir, Bank dan Lembaga Keuangan Lainnya, Jakarta, Raja Grapindo Persada, 2001

Bank dan Lembaga Keuangan Lainnya (Edisi Revisi 2001), Jakarta, Rajawali Pers, 2001

Karim, Adiwarman. Ekonomi Mikro Islam, Jakarta, IIIT Indonesia, 2002

Saddam, Muhammad. Ekonomi Islam (Sistem Ekonomi Menurut Islam), Jakarta,Taramedia, 2002.

Sanafiyah Faisal, Format-format Penelitian Sosial, Jakarta, Rajawali Press, 1995.

Syafi'I Antonio, Muhammad. Bank Syari'ah dari Teori ke Praktek, Jakarta, Gema Insani Press, 2001

Surakhmad, Winarno. Pengantar Penelitian Ilmiyan, Bandung, Tarsindo, 1982

Sabiq, Sayyid. al-Fiqh al-Sunnah, Beirut, Dar al-Fikr, 1995

Winarno Surakhmad, Pengantar Penelitian Ilmiyan, Bandung, Tarsindo, 1982.

Yusanto, Muhammad Ismail. dan Muhammad Karebet Widjajakusuma, Menggagas Bisnis Islam, Jakarta, Gema Isnsani, 2002

Zuhaily, Wahbah. al-Fiqh al-Islam wa Adillatuh, Beirut, Dar al-fikr, 2002 